\title{
Economic Analysis of Maize Production in Central Khyber Pakhtunkhwa, Pakistan
}

\author{
Murtaza $^{1}$, Syed Attaullah Shah ${ }^{*}$, Shahid Ali ${ }^{1}$, Amjad Ali ${ }^{1}$ and Asia Baig ${ }^{2}$
}

${ }^{1}$ The University of Agriculture Peshawar, Khyber Pakhtunkhwa, Pakistan; ${ }^{2}$ Department of Economics, Abdul Wali Khan University, Mardan, Khyber Pakhtunkbwa, Pakistan.

\begin{abstract}
This study looked at profitability of maize crop and estimated growers' technical efficiency in central Khyber Pakhtunkhwa, Pakistan. Stochastic Frontier analyses were conducted over primary data, collected from randomly selected 119 maize growers. Profitability analysis confirmed high net-return for hybrid maize as compared to local maize crop. The estimated Stochastic Frontier Model-1 showed that maize yield is positively affected by hybrid seed cultivation, irrigation, organic and inorganic fertilizers application. The model predicted mean technical efficiency of $85 \%$ with a maximum possible of $97 \%$. This indicates that $12 \%$ increase in yield is possible with the existing production technology. Results for the Stochastic Frontier Model-2 identified head's formal education, farming experience and level of involvement in agriculture and combined family structure as important factors significantly reducing inefficiency in maize production. The study recommends formal education and agricultural training for maize growers, provision of subsidy for hybrid seeds and chemical fertilizers and price support for their produce during harvest season.

Received | March 16, 2019; Accepted | January 28, 2020; Published | September 08, 2020

*Correspondence | Syed Attaullah Shah, The University of Agriculture Peshawar, Khyber Pakhtunkhwa, Pakistan; Email: syedshah313@gmail.com Citation | Murtaza, S.A. Shah, S. Ali, A. Ali and A. Baig. 2020. Economic analysis of maize production in central Khyber Pakhtunkhwa, Pakistan. Sarhad Journal of Agriculture, 36(3): 966-973.

DOI | http://dx.doi.org/10.17582/journal.sja/2020/36.3.966.973

Keywords | Maize growers, Stochastic frontier production function, Yield determinants, Technical efficiency determinants, Central Khyber Pakhtunkhwa, Pakistan
\end{abstract}

\section{Introduction}

$\mathrm{M}$ aize (Zea mays L.), a member of grass family (Gramineae) originated in Central America, is used by human civilization even in the ancient times. Maize is a C4 plant, having high genetic potency and is a photosynthesis explorative crop. Maize grain contains about $79 \%$ starch, $10 \%$ protein, $4 \%$ fiber, 4\%fat and 3\% minerals (Ahmad et al., 2017). It is mostly grown for grain as well as for fodder purposes and is also used as a raw material by various manufacturing units like cooking oil, confectionary and backers.

The global maize production is approximately $1,060.2$ million tonnes on an area of 188 million hectares with an average yield of 5.63 tonnes per hectare (USDA, 2016-17). Among the 176 countries worldwide, United States is ranked first with the production of 370.96 million tonnes on an area of 33.4 million hectares. China, Brazil, European Union and Argentina are the other top ranked maize producing countries. Pakistan comes at $17^{\text {th }}$ place in the ranking.

In Pakistan, maize was cultivated on an area of 1.3 million hectares in 2014-15 with a total production of about 6 million tonnes and an average yield of 4.32 tonnes hec ${ }^{-1}$. The average production in Pakistan is less than world's average by 1.02 tonnes hec ${ }^{-1}$. Provincial statistics for the same year, provided in Table 1, show that among all the 4 provinces of Pakistan, Punjab is on top, and where the average yield (5.98 tonnes hec ${ }^{-1}$ ) 
is slightly better than the global average yield level. The yields per hectare in Khyber Pakhtunkhwa, Sindh and Balochistan are significantly lower than that of Punjab.

Table 1: Provincials statistics for area, production and yield of maize (2014-15).

$\begin{array}{llll}\text { Province } & \text { Area }(\mathbf{0 0 0} \text { ha) } & \begin{array}{l}\text { Production } \\ \text { (000Tonnes) }\end{array} & \begin{array}{l}\text { Yield } \\ \text { (Tonnes) }\end{array} \\ \text { Punjab } & 672.8 & 4019.90 & 5.975 \\ \text { Khyber Pakhtunkhwa } & 463.0 & 909.70 & 1.965 \\ \text { Sindh } & 3.2 & 3.40 & 1.063 \\ \text { Baluchistan } & 3.5 & 3.80 & 1.086 \\ \text { Pakistan } & 1142.5 & 4936.8 & 4.321\end{array}$

Source: Agriculture Statistics of Pakistan (2014-15).

This low yield in Khyber Pakhtunkhwa, Sindh and Balochistan might be due to old farming technology, underutilization of farm inputs or insufficient water for irrigation. Thus, more comprehensive research is required to investigate factors that could directly or indirectly augment maize yield and reduces growers inefficiency. That's why this study was designed to examine the inputs and technological usage in maize production at Central Khyber Pakhtunkhwa; investigate yield and profitability of the growers there; and estimate their technical inefficiency and identify its determinants.

\section{Literature review}

Literature review helps in generating research ideas and their refinement. It serves as a guideline for selecting proper method for sampling, data collection and their analysis. It also helps in discussion of results and their justification. For this study, the most relevant published research work is presented below in chronological order.

Seyoum et al. (1998) investigated the maize producers' technical efficiency in two sub samples of eastern Ethiopia-farmers within the Sasakawa-Global 2000 project and farmers outside this program. Stochastic Frontier Production functions was used and technical inefficiency effects was assumed to be the function of the farmer's age and education and contact with extension agent. A Cobb-Douglas type production function was used on cross-sectional data set. Results indicated that farmers within the SG 2000 project were more technically efficient than farmers outside the project. The average output of the growers within the SG 2000 project was significantly greater than that for the growers outside the project.
Zalkuwi et al. (2010) conducted Stochastic Frontier analysis over a primary data set collected from 200 randomly selected maize growers in Nigeria to identify yield determinants. Results revealed seeds, labor, fertilizer and herbicides as important determinants having positive effects on maize yield. They recommended mobilization of extension agents, provision of adequate credit and availability of improved seed varieties for obtaining high maize yield in the study area.

Naqvi and Ashfaq (2013) measured technical efficiency for hybrid maize production. First, a Translog production functions in Stochastic Frontier analysis was estimated to identify important determinants of maize yield and predict technical efficiency in production. They found a mean technical efficiency of 0.81 . Then the estimated results for efficiency analysis revealed that old and experienced growers were more efficient than the younger ones due to their managerial skills and proper knowledge. They recommended formal knowledge and agricultural training in inputs and new farming practices for the maize growers.

Sihlongonyane et al. (2014) examined the technical and allocative efficiency of maize growers in Swaziland. They obtained $100 \%$ efficiency in cost minimization while the estimated technical efficiency was $64.73 \%$, revealing that more improvement is possible with the given production technology.

Sienso et al. (2014) estimated the technical and allocative efficiency of maize growers in Ghana. They found positive significant effects for farm size, seeds, labor, agrochemicals and fertilizers over maize yield, and their estimated mean technical efficiency was 91\%. They recommended training of extension staff to facilitate farmers in improving their production efficiency.

Bempomaa et al.(2014) measured technical efficiency for maize growers in Ghana. Variables, such as land, labor and fertilizers were determined as important factors affecting maize yield. The estimated mean technical efficiency level was $67 \%$. Female farmers were technically more efficient than men. Credit availability, education level and farming experience affected efficiency positively. They recommended education and proper agricultural training for maize growers. 
Ahmad et al. (2017) conducted a study at different agro-climatic zones in Bihar to assess the growth in area, productivity and technical efficiency of maize growers. Results showed growth in area, production and productivity during the 15 years period. The mean technical efficiencies for Rabi and Kharif maize crop were $71 \%$ and $64 \%$, respectively.

Bati et al. (2017) assessed the economic, technical and allocative efficiencies in maize production in Ethiopia. The estimated mean economic, allocative and technical efficiencies were $30.62 \%, 37.45 \%$ and $81.78 \%$, respectively. Education level of the growers was the key factor affecting all the efficiencies level. The study forwarded recommendation for the government and policy makers to pay attention to formal education and training of the growers.

This literature review revealed that Stochastic Frontier approach is the most preferred method used for estimating a crop yield; identification of its determinants and measurement of inefficiency in production. Also, it determines factors affecting inefficiency in production. It was observed that the mean technical efficiency for maize growers ranges from $63 \%$ to $91 \%$, and that their age, education and agricultural experience are important determinants of efficiency in maize production.

\section{Materials and Methods}

\section{Data collection}

The Central KP is blessed with fertile land and plenty of freshwater. This zone is famous for cultivation of tobacco, sugarcane, wheat and maize. Maize crop is cultivated on an area of 73442 hectares with a total production of 190555 tonnes. The yield per hectare is 2.50 tonnes which is almost half of the yield in Punjab province (ASP, 2015-2016).

Administratively, the central zone of Khyber Pakhtunkhwa is comprised of Peshawar, Charsadda, Nowshera, Mardan and Swabi districts. A multistage random sampling technique was used to select a sample of maize growers from Central Khyber Pakhtunkhwa. Due to budget and time constraints Mardan district was purposively selected out of the five districts. Mardan is the leading maize producing district in Central Khyber Pakhtunkhwa, and its part in maize cultivated area and production is 40 percent and 47 percent, respectively (ASP, 2015-2016).
The district was further divided into its three thesils; Mardan tehsil and its three rural union councils, namely Narshak, Bakhshali and Baghecha Dheri, were randomly selected in subsequent sample stages. Finally, a sample of 119 maize growers was randomly selected from the three selected union councils. The total sample size was decided based on Yamane's formula. Proportional Allocative Sampling procedure was used to find out the required number of maize growers from each village.

$$
n=\frac{N}{\left(1+N(e)^{2}\right)}
$$

Where;

' $\mathrm{n}$ ' is the sample size; ' $\mathrm{N}$ ' is the population of maize growers in the selected villages and 'e' is the level of precision or minimum possible error.

$$
n i=\frac{N i}{N} \times n
$$

Where;

$\mathrm{N}$ is the total number of maize growers in the selected villages; $\mathrm{Ni}$ is the total number of maize growers in the ith selected village; $n_{i}$ is the required number of maize growers in the sample from ith village; and $n$ is the overall sample size.

To collect the required data from sampled maize growers, a questionnaire was designed based on the objectives of the study and was pretested in the field. All sampled maize growers were interviewed personally at their farms and at their homes.

\section{Analytical framework}

Data on maize growers' socio-economic and agricultural characteristics were analyzed using descriptive statistical tools, such as meanand standard deviation. Stochastic Frontier Production approach was used to identify important determinants of maize yield, estimate technical inefficiency for the sampled maize growers' and investigate factors affecting its level. The method was first introduced by Farrell (1957).

Stochastic Frontier analysis involves the estimation of the following two models:

Model-1: It estimate yield (Y) as a function of production inputs $(\mathrm{X})$. This function is different from other production functions because of the composed error term involved in it. 
Mathematically, the general form of a production function can be written as;

$$
Y=f(X) \ldots \ldots(1)
$$

Where;

$Y$ is a crop yield which depends on $X$, a set of important production inputs utilized during production. The association between $\mathrm{Y}$ and $\mathrm{X}$ could take linear, log$\log$ or $\log$-linear form.

In recent studies, researchers suggest a Translog form (a type of log-log functional form) for this production function. It has the advantage of providing inputs interaction effects along with their partial effects on yield. However, estimated Translog models suffer from multicollinearity problem. For this reason, this study used the following Cobb-Douglas type of production function for estimating maize yield in the study area. Cobb-Douglas type of production function is a special form of the Translog production function which assumes no inputs interaction effect.

$\ln Y_{i}=\beta_{0}+\beta_{1} \ln \left(T_{i}\right)+\beta_{2} \ln \left(L_{i}\right)+\beta_{3} \ln \left(W_{i}\right)+\beta_{4} \ln \left(U_{i}\right)+\beta_{5} \ln \left(D_{i}\right)+\beta_{6} \ln \left(C_{i}\right)+\beta_{7} D_{1}+\beta_{8} D_{2}$ $+\left(V_{i}-U_{i}\right) \quad \ldots .(2)$

Where;

$L n$ : Natural log; $Y_{i}:$ Kilogram of maize grain produced per acre by $i^{\text {th }}$ grower; $B s$ : Coefficients in the model; $T i$ : Tractors hours per acre by $i^{\text {th }}$ grower; $L i$ : Labor hours per acre by $i^{\text {th }}$ grower; $W i$ : Number of irrigation applied per acre by $i^{\text {th }}$ grower; $U i$ : Kilogram of Urea fertilizer applied per acre by $i^{\text {th }}$ grower; $D i$ : Kilogram of DAP fertilizer applied per acre by $i^{\text {th }}$ grower; $C i$ : Liters of herbicides/ pesticides applied per acre by the $i^{\text {th }}$ grower; $D_{i}$ : Dummy variable 1 , equals to 1 for hybrid seeds, otherwise $0 ; D_{2}$ : Dummy variable 2 , equals to 1 if FYM is applied, otherwise 0 ; $V$ : Normally distributed error-term $\left(\sim \mathrm{N}\left(0, \sigma^{2}\right)\right)$.

Model-2: This model presents technical inefficiency $\left(\mathrm{T}_{\text {ineff }}\right)$ as a function of growers' socio-economic characteristics $(\mathrm{S})$.

$$
T_{\text {ineff }}=f(S) \quad \ldots(3)
$$

The estimated Model- 1 is used to predict technical inefficiency level for each observation. The predicted values for technical inefficiency are then used with growers' socio-economic data to estimate Model-2.

$T_{\text {ineff } i}=\delta_{0}+\delta_{1} E d_{i}+\delta_{2} E x_{i}+\delta_{3} I_{i}+\delta_{4} F S_{i}+\delta_{5} T S_{i}+\varepsilon_{i}$
Where;

$\delta s$ : coefficient of Model $-2 ; E d:$ Education level of $i^{\text {th }}$ grower; $E x_{i}$ : Agricultural experience of the $i^{\text {th }}$ grower; $I_{i}$ : Income source of the grower ( 1 for agriculture, 0 otherwise); $F S_{i}$ : Family System (1 for the joint family, 0 otherwise); $T S_{i}$ : Tenure status (1 for owners, 0 otherwise).

\section{Results and Discussion}

\section{Socio-economic characteristics of the maize growers}

Socio-economic characteristics of a grower, such as age, education, farming experience, household income, farm size, etc., affect his technical efficiency in crops production. The descriptive statistics for socio-economic characteristics of the sampled maize growers are given in Table 2. It shows that maize growers were on average 45.42 years old; their average formal education and agricultural experience were 4.04 years and 24.58 years, respectively. All of them were cultivating maize crop in irrigated ecology and their average farm size of 3.23 acres. Data on household characteristics of the selected growers show that their average family size was 8 individuals, and average monthly income and daily per capita income were Rs.40596 and Rs.169, respectively.

Table 2: Socio-economic characteristics of the sampled maize growers.

$\begin{array}{lllll}\text { Particulars } & \text { Mean } & \text { Maximum } & \text { Minimum } & \text { S.D } \\ \text { Age (Years) } & 45.2 & 68.00 & 25.00 & 10.07 \\ \text { Education (Years) } & 4.04 & 12.00 & 0.00 & 4.42 \\ \text { Farming Exp. (Year) } & 24.58 & 50.00 & 5.00 & 10.32 \\ \text { Farm size (Acres) } & 3.23 & 11.00 & 1.00 & 1.72 \\ \text { Family size } & 8.00 & 16.00 & 4.00 & 3.00 \\ \text { Income Level (Rs.) } & 40596 & 85000 & 17000 & 13820\end{array}$

Source: Survey data, 2017.

\section{Maize cost of production}

The aggregate cost on maize crop produced per acre was derived by adding on-farm production cost and transportation cost. On-farm production cost was calculated by adding fixed and variable costs. Land rent was taken as fixed cost, while costs on machinery, seeds, labour, inputs and irrigation were considered as variable costs.

Total on-farm production cost was estimated Rs. 33813, which is almost 96 percent of the aggregate cost of Rs.35237acre ${ }^{-1}$. The main components of the on-farm production cost are: 
Land rent: Agricultural land in Mardan district is comparatively more productive for maize crop as compared to other districts in Central Khyber Pakhtunkhwa. The average annual land rent in the selected villages was Rs. 30000 . Based on standing crop duration the land cost for maize crop was calculated from the annual land rent which was on average Rs.15155.46 per acre. It makes 38.51 percent of the total cost of production on maize crop.

Seed cost: Seed used by growers were classified as local seeds and hybrid seeds. The average cost of the hybrid seeds (Rs. 4692.22 per acre) was significantly greater than local seed cost (Rs.464.65). The combined average cost for both the hybrid and local seeds was Rs. 3661.97 per acre, which is around 9.30 percent to the total cost.

Machinery cost: Machinery was used to prepare land for seed sowing. For hybrid seeds, tractor was used to plough field and make small furrows. Sowing was done through specialized tool to maintain the required plant to plant distance. For local seeds, field was simply ploughed thorough tractor or bullock and seeds were broadcasted by labour.

For the sampled growers, the cost for all these activities was on average Rs.4500 per acre.

Labour cost: Labour were used for sowing, inputs application, irrigation, weeds control, harvesting and transportation. The daily wage rate in the study area was Rs.600 and the aggregate labour cost per acre on maize crop was estimated Rs.8225.21, which is around 11 percent of the total production cost on maize.

Inputs cost: To get high yield for maize crops, growers applied farm yard manure, inorganic fertilizers (Urea and DAP) and herbicides/ pesticides at various stages of production. The quantity applied and cost incurred per acre on each of these inputs is listed in Table 2. Cost on these inputs was around 17 percent of the total production cost per acre.

Irrigation cost: To irrigate maize crops, all of the sampled maize growers were using canal water from Swat River. The canal water charges for the whole maize season were Rs.491.59 per acre, which is 1.24 percent to the total cost.

Transportation cost: It was derived by adding threshing, packing and transportation charges. The average transportation cost was Rs. 1424.11acre ${ }^{-1}$ (Table 3).

\section{Maize yield and net-return}

The average grain yield of the sampled maize growers was 1412.43 kilograms per acre, and the by-product was around 456.93 bushels (Table 4). Data collected for hybrid and local seeds revealed a significant difference in yield. The average yield per acre for hybrid seeds (1720 kilograms) was greater than for local seeds (950 kilograms) by 850 kilograms.

The average net-return from maize was Rs.5293.75 per acre, and the estimated average net-return from local and hybrid maize were Rs.950 and Rs.8189.50, respectively. The net-return for hybrid maize was greater than the local by Rs.7239. This reveals that the cultivation of hybrid maize is comparatively more profitable. The estimated profitability ratio for hybrid maize is 0.20 , which means a one rupee investment on hybrid maize would generate a profit of 0.20 rupees, while the same value is almost zero for local maize.

\section{Stochastic frontier analysis}

The Maximum Likelihood estimates of the CobbDouglas type Stochastic Frontier Model-1 for maize yield are given in Table 5. The estimated coefficient for an explanatory variable represents the elasticity in yield to that specific variable, and the summation of the coefficients for all of the explanatory variables gives return to scale in maize production. The $\mathrm{Z}$-value and $\mathrm{P}$-value associated with an estimated coefficient presents its statistical significance.

The estimated coefficients for hybrid seed, machinery, irrigation, Urea, DAP and FYM are positive and statistically significant at 5\% level of significance, indicating that each of these variables has a positive effect on maize yield. The sum of the estimated coefficients for of all the variables is 1.22 , indicating increasing returns to scale in maize production with existing technology. Thus increase in the utilization of the following factors would result a significant increase in maize yield.

Hybrid seeds: The coefficient for hybrid seed, a dummy variable ( 1 if hybrid seed, 0 for local seed), is 0.374 , indicating that holding other variables constant the yield for hybrid seed would be greater by 37 percent from that of the local seed. Discussion 
Table 3: Average cost of production for maize crop (per acre).

$\begin{array}{llllll}\text { Variables } & \text { Unit } & \text { Cost/unit (Rs) } & \text { Quantity } & \text { Total cost } & \text { \%age } \\ \text { Land rent } & \text { Rs. } & 15155.46 & 1 & 15155.46 & 43.01 \\ \text { Seeds } & \text { Kgs } & 420.46 & 8.7089 & 3661.97 & 10.39 \\ \text { Tractor } & \text { Hours } & 1,000 & 3.3445 & 3344.53 & 9.49 \\ \text { Bullocks } & \text { Days } & 500 & 1.9789 & 989.49 & 2.81 \\ \text { DAP } & \text { Kgs } & 58 & 25.672 & 1488.99 & 4.23 \\ \text { Urea } & \text { Kgs } & 29 & 85.546 & 2480.84 & 7.04 \\ \text { Pesticides } & \text { Bottles } & 414.16 & 1.9243 & 796.89 & 2.26 \\ \text { FYM } & \text { Trolleys } & 3,000 & 0.4301 & 1290.58 & 3.66 \\ \text { Labour hours } & \text { Hours } & 75 & 54.834 & 4112.55 & 11.67 \\ \text { Irrigation } & \text { No. } & 88.77 & 5.5372 & 491.59 & 1.40 \\ \text { Production cost } & & & & 33812.89 & 95.96 \\ \text { Transportation cost } & \text { Rs. } & & & 1424.118 & 4.04 \\ \text { Total cost } & \text { Rs. } & & 35237.008 & 100\end{array}$

Source: Survey data 2017.

Table 4: Maize yield and net-return estimates (per acre).

\begin{tabular}{llllllll} 
Maize Crop from & Yield (Kgs) & \multicolumn{2}{l}{ Revenue (PKR) } & \multicolumn{2}{l}{ Total } & \multicolumn{2}{l}{$\begin{array}{l}\text { Net revenue Profitability } \\
\text { cost(Rs) }\end{array}$} \\
& & Grain & by-product & Total & ratio \\
Local seeds & 950.00 & 23750.00 & 4200.00 & 27950.00 & 27000.00 & 950.00 & 0.04 \\
Hybrid seeds & 1720.70 & 43017.50 & 5900.00 & 48917.50 & 40728.00 & 8189.50 & 0.20 \\
Average & 1412.43 & 35310.75 & 5220.00 & 40530.75 & 35237.00 & 5293.75 & 0.15
\end{tabular}

Source: Survey data, 2017.

with selected maize growers revealed that they prefer to grow local white seed variety to get grain for their own consumption. The available hybrid seeds in local market are yellow; their produced grain is utilized mostly for poultry feeds, cereals products and oil extraction. The other problem with hybrid seeds is their high market prices. The introduction of white hybrid seeds at subsidized prices could encourage growers to adopt them, and hence the objective of high yield can be achieved.

Increased inputs usage: Increase use of FYM, Urea and DAP fertilizers with irrigation at proper times would increase in maize yield. FYM and DAP fertilizer are applied before seed sowing stage, while Urea fertilizer with irrigation give best results at the initial stage of maize crop. The estimated coefficient of chemicals (pesticides and herbicides) is positive but insignificant that might be due to the fact that most of the farmers didn't use the chemicals in time or they didn't use appropriate dose. Almost same and positively significant results for fertilizers, chemicals and irrigation were obtained by Sihlongonyane et al. (2014) while estimating the Technical and Allocative
Efficiency of maize growers in Swaziland.

Table 5: Estimated stochastic frontier Model-1 (SFM1) for maize yield.

\begin{tabular}{lllll} 
Explanatory Variables & \multicolumn{2}{l}{ Coefficients S.E } & Z-ratio & P-valu \\
Ln (Machinery Hours) & 0.241 & 0.088 & 2.71 & 0.007 \\
Ln (Labor Hours) & 0.069 & 0.064 & 1.07 & 0.286 \\
Ln (Irrigation numbers) & 0.191 & 0.071 & 2.69 & 0.007 \\
Ln (Urea in Kgs) & 0.207 & 0.064 & 3.19 & 0.001 \\
Ln (DAP in Kgs) & 0.037 & 0.008 & 4.19 & 0.000 \\
Ln (Chemicals in liters) & 0.002 & 0.093 & 0.03 & 0.975 \\
Hybrid Seed (Dummy) & 0.374 & 0.039 & 9.58 & 0.000 \\
FYM (Dummy) & 0.101 & 0.033 & 3.01 & 0.003 \\
Constant & 5.046 & 0.336 & 15.01 & 0.000 \\
Variance Parameter & & & & \\
Sigma-v & 0.061 & 0.012 & 5.93 & 0.000 \\
Sigma-u & 0.202 & 0.019 & 6.16 & 0.000 \\
Gamma & 0.728 & & &
\end{tabular}

Source: Authors' estimates from survey data, 2017.

Mechanized farming: The coefficient for machinery hours utilized in maize production is 0.24 , indicating 
that a one percent increase in machinery utilization in maize production could increase yield by 0.24 percent. The effect of labor hours is positive but statistically insignificant. These findings suggest that maize yield can be increased significantly through mechanized production. Same results were obtained by Bempomaa et al. (2014) while studying technical efficiency of maize crop.

The variance parameter gamma $(\gamma)$ was estimated 0.72 , indicating that 72 percent of the variation of the actual maize yield from frontier yield is due to the inefficiency of the growers' and the remaining 28 percent of the variation is due to uncontrolled random factors which are not in the control of growers.

Table 6: Estimated Stochastic Frontier Model-2 for inefficiency in maize production.

$\begin{array}{lcccc}\text { Explanatory Variables } & \begin{array}{c}\text { Coeffi- } \\ \text { cients }\end{array} & \text { S.E } & \text { Z-ratio } & \text { P-value } \\ \text { Joint Family System } & -1.650 & 0.466 & -3.540 & 0.000 \\ \text { Involvement in Agriculture } & -1.388 & 0.413 & -3.360 & 0.001 \\ \text { Tenure Status } & -0.199 & 0.375 & -0.530 & 0.595 \\ \text { Education Years } & -0.114 & 0.038 & -2.950 & 0.003 \\ \text { Farming Experience } & -0.046 & 0.012 & -3.820 & 0.000\end{array}$

Source: Authors' estimates from survey data, 2017.

The predicted mean technical efficiency of maize growers in the study area ranged between the minimum value of 0.537 percent and the maximum of 0.97 percent with a mean level of 0.85 (inefficiency level is 0.12). It means that maize growers are about 12 percent below the production frontier. In other words, on average the maize growers could increase their efficiency by 12 percent to reach the maximum level of efficiency. It was observed in the literature review that the average technical efficiency for maize growers' in developing countries ranged from 63\% to 91\%, Nehring et al. (2006) found in the United States' Corn Belt (Iowa, Illinois and Indiana States), technical efficiency in maize production was $63 \%$. The estimated technical efficiency for maize grower in this study lies above the average world level (around 80\%). Bravo-Ureta et al. (2007) conducted meta-analysis of technical efficiency and they concluded that the highest efficiency averages were those of Western Europe and Australian farmers. On the contrary, the lowest levels of efficiency in agriculture were found in Eastern Europe, Asia, Africa, Latin America and North America.
Estimated results for Stochastic Frontier Model-2 are given in Table 6. Results reveal growers' formal education, farming experience and his full time involvement in agriculture and joint family system as important determinants having negative significant effects on inefficiency in maize production.

\section{Conclusions and Recommendations}

Findings of the study revealed that hybrid maize crop generate significantly high net-return to growers as compared to local maize. However, the cost of production for local maize is significantly lower than hybrid maize, and because of this the growers prefer local maize as a fodder crop for livestock.

The Estimated Stochastic Frontier Production Model-1 showed that seed variety, tractor hours, Urea, DAP, FYM and irrigation had positive significant effects on maize yield. The estimated technical inefficiency in the study area was 15 percent on average. Results from Stochastic Frontier Model-2 identified farmer's formal education, agricultural experience and involvement level in agriculture and joint family structure as factors reducing inefficiency in maize production.

The study recommends government and other concerned organizations to provide formal education and agricultural training to farming community. Provision of subsidies on important agricultural production inputs, such as chemical fertilizers and hybrid seeds, and price support on market price during harvest season would improve growers' return from this crop.

\section{Acknowledgements}

This research work titled "Economic Analyses for Maize Production in Central Khyber Pakhtunkhwa, Pakistan" was carried out in collaboration among all authors. Mr. Murtaza conducted the study, analyzed the data and wrote first draft of the manuscript. Author Dr. Syed Attaullah Shah ${ }^{2}$ developed main theme of the study, interpreted results and helped in abstract writing. Author Dr. Shahid Ali ${ }^{3}$ reviewed literature, helped in model specification and writing conclusions and recommendations. Dr. Amjid Ali 
and Ms. Asia Baig held in data analyses. All authors read and approved the final manuscript.

\section{Novelty Statement}

Central Khyber Pakhtunkhwa (Peshawar Valley) is the main maize producing zone of the Khyber $\mathrm{Pa}^{-}$ khtunkhwa Province. The agro-climatic conditions of the valley support growing two maize crops per single Kharif season. Inspite of having advantage of suitable agro-climatic conditions, the yield per acre for maize crop is significantly lower than the average yield in irrigated ecology of Punjab province. This study was designed to investigate factors responsible for low yield of maize crop and forward recommendations to local government for appropriate policy intervention.

\section{Author's Contribution}

Murtaza: Conducted the study and wrote the first draft.

Syed Attaullah Shah: Deveoped main theme of the study, interpreted results and helped in abstract writing.

Shahid Ali: Reviewed literature, helped in model specification and writing of the manuscript.

Amjad Ali: Helped in data analysis.

Asia Baig: Helped in data analysis and results and discussion.

\section{Conflict of interest}

The authors have declared no conflict of interest.

\section{References}

Ahmad, N., D.K. Sinha, K.M. Singh and R.R. Mishra.2017. Growth performance and resource use efficiency of maize in Bihar: An economic perspective. MPRA Paper No. 80267. Online at https://mpra.ub.uni-muenchen.de/80267/.

ASP.2014-15.Department of revenue and statistics, Islamabad.

ASP.2015-16.Department of revenue and statistics, Islamabad.

Bati, M., M. Tilahun and R.K. Parabathina. 2017. Economic efficiency in maize production in Ilu Ababor zone, Ethiopia. Res. J. Agric. For. Sci.,
5(12): 01-08.

Bempomaa, B. and H.D.G. Acquah.2014. Technical efficiency analysis of maize production: evidence from Ghana. APSTRACT. Appl. Stud. Agribus. Commerce, 8(2-3): 73-79. https://doi. org/10.19041/Apstract/2014/2-3/9

Bravo, U.B., D. Solis, V. Moreira, J. Maripami, A. Thiam and T. Rivas. 2007. Technical efficiency in farming: a meta-regression analysis. J. Prod. Anal. 27(1): 57-72. https://doi.org/10.1007/ s11123-006-0025-3

Farrell, M.J., 1957. The measurement of productive efficiency.J.R.Stat.Soc.Ser.A(General), 120(3): 253-281. https://doi.org/10.2307/2343100

Naqvi, S.A.A. and M. Ashfaq. 2013. Technical efficiency analysis of hybrid maizeproduction using translog model case study in District Chiniot, Punjab (Pakistan). Agric. Sci., 4(10): 536-544. https://doi.org/10.4236/ as.2013.410072

Nehring, R., D. Barnard, C. Banker and B. Vince. 2006. Urban influence on costs of production in the corn belt. Am. J. Agric. Econ. 88(4): 930-946. https://doi.org/10.1111/j.14678276.2006.00907.x

Sienso, G., S.A. Brempong and D.P.K. Amegashie. 2014. Estimating the efficiency of maize farmers in Ghana. Asian J. Agric. Ext., Econ. Sociol., 3(6): 705-720. https://doi.org/10.9734/ AJAEES/2014/11646

Sihlongonyane, M.B., M.B. Masuku and A. Belete. 2014. Economic efficiency of maize production in Swaziland. Res. Appl. Econ., 6(3): 179-195. https://doi.org/10.5296/rae.v6i3.6045

Seyoum, E.T., G.E. Battese and E.M. Fleming. 1998. Technical efficiency and productivity of maize producers in eastern Ethiopia: a study of farmers within and outside the Sasakawa-Global 2000 project. Agric. Econ., 19(3): 341-348. https://doi.org/10.1111/j.1574-0862.1998. tb00536.x

United States Department of Agriculture. (201617). http//www.usda.gov.

Zalkuwi,J.W.,Y.Z.Dia and R.Z.Dia.2010.Analysis of economic efficiency of maize production in Ganye local Government Area Adamawa state, Nigeria. Nassarawa: www. sciencepub.net/ report. 